\title{
Key habitat and home range of mulloway Argyro- somus japonicus in a south-east Australian estuary: finding the estuarine niche to optimise stocking
}

\author{
Matthew D. Taylor ${ }^{1, *}$, Shawn D. Laffan ${ }^{1}$, D. Stewart Fielder ${ }^{2}$, Iain M. Suthers ${ }^{1}$ \\ ${ }^{1}$ School of Biological, Earth and Environmental Science, University of New South Wales, Sydney, \\ New South Wales 2052, Australia \\ ${ }^{2}$ Port Stephens Fisheries Centre, New South Wales Fisheries, Taylors Beach, New South Wales 2316, Australia
}

\begin{abstract}
The preferred habitats, home range and activity patterns of sub-adult mulloway Argyrosomus japonicus (Sciaenidae) in the Georges River, New South Wales, Australia, were investigated using ultrasonic telemetry. Tags were surgically implanted in 9 hatchery-reared and 12 wild-caught mulloway (330 to $730 \mathrm{~mm}$ total length, TL). Fish were tracked for 2 periods of continuous tracking over $72 \mathrm{~h}$ in a $15 \mathrm{~km}$ section of river, once daily for a $20 \mathrm{~d}$ period, and up to 3 times $\mathrm{mo}^{-1}$ for $11 \mathrm{mo}$. Key habitats were identified as discrete holes or basins up to $20 \mathrm{~m}$ deep. Mulloway preferred this deep hole habitat as small fish (hatchery-reared, 300 to $500 \mathrm{~mm}$ TL) remained in these deep holes both day and night, while large fish (wild, 500 to $800 \mathrm{~mm} \mathrm{TL}$ ) ventured outside the holes at night. Maximum home range of small and large mulloway was 6000 and $17710 \mathrm{~m}^{2}$, respectively, and home range correlated significantly with length. Small fish moved up to $7 \mathrm{~km} \mathrm{~d}^{-1}$ while large fish moved up to $16 \mathrm{~km} \mathrm{~d}^{-1}$. Small fish released in shallow water initially had significantly greater movements than those released directly over deep holes, with movement up to $10 \mathrm{~km}$ in $3 \mathrm{~d}$. Activity patterns varied between small and large fish, with significantly larger movements by large fish during the night and early morning than daytime. Five wild-caught mulloway tracked over 11 mo showed strong fidelity to holes within their particular home range. Mulloway should be stocked directly into their deep holes to minimise movements. The use of key habitats by mulloway indicate that their survival will be sensitive to stocking density. Optimal stocking density could be estimated from the area of key habitat in the target estuary.
\end{abstract}

KEY WORDS: Argyrosomus japonicus $\cdot$ Mulloway $\cdot$ Key habitat $\cdot$ Home range $\cdot$ Activity $\cdot$ Stocking density $\cdot$ Diel migration $\cdot$ Stock enhancement $\cdot$ Homing

\section{INTRODUCTION}

Mulloway Argyrosomus japonicus (Sciaenidae) are an elusive sportfish endemic to the estuarine and coastal areas of southern Australia and southern Africa. In Australia, mulloway represent an important recreational fishery, with over 975 tonnes taken by recreational fishers in 2000 (Henry \& Lyle 2003). The species reaches the current New South Wales minimum legal size of $45 \mathrm{~cm}$ in $\sim 20 \mathrm{mo}$, and the species can grow to a maximum length of $1.8 \mathrm{~m}$ and maximum weight of $75 \mathrm{~kg}$ (Griffiths 1997). Estuarine commercial catches of mulloway in New South Wales have recently declined from approximately 47 tonnes in 1983-84 to 29 tonnes in 1999-2000 (NSW Fisheries Commercial Catch Statistics Database). Due to this decline and the possibility of recruitment limitation, pilot studies investigating mulloway stock enhancement have commenced (Taylor et al. 2005). These studies are following the responsible approach to marine stock enhancement (Blankenship \& Leber 1995) and using pilot-scale releases to refine stocking strategies and minimise adverse effects on conspecifics, forage species or competitors. 
Survival of any stocked fish depends on evaluating ecosystem resources, particularly in terms of habitat. Key habitats in the marine environment must satisfy food and refuge requirements, especially for juveniles, and enable optimal release locations to be identified. Only resources in the close vicinity of refugia may be efficiently exploited by stocked juvenile fish, which try to minimise predation risk (Walters \& Martell 2004). Past evaluations of carrying capacity to support stocked fish only consider absolute abundance of species at each trophic level (e.g. cod, Salvanes et al. 1992, Cooney et al. 1993). While useful, such complex assessments may not be relevant if habitat necessary for shelter from predation (refugia) is not accounted for. Therefore, carrying capacity needs an initial assessment of key habitat availability and use of that habitat by predatory finfish species. Identification of key habitats for species targeted for stocking will mean fish can be released into the appropriate habitat at the appropriate density.

Ultrasonic transmitters have been used both in conjunction with and as an alternative to tag release and recapture studies to track fish movements and resolve habitat use (Holland et al. 1985, Zeller 1997, Lowry \& Suthers 1998). Ultrasonic technology now allows the use of transmitters in smaller fish, but has rarely been extended to resolve the habitat use of hatchery-reared and wild fish after stocking (e.g. Bradford \& Gurtin 2000, Miller \& Walters 2004). Importantly, there are no published examples of ultrasonic telemetry used to investigate the movement patterns of any sciaenid species, including red drum Sciaenops occelatus in the
Gulf of Mexico where as many as 30 million fish may be stocked annually (McEachron \& Daniels 1995).

The habitat use and migration of sciaenid species in Australia and elsewhere remains relatively unknown (Gray \& McDonall 1993, Silberschneider \& Gray 2005). African Argyrosomus japonicus are most abundant in inshore areas during spring and summer, and tend to move into deeper offshore areas in winter (Smale 1985). In eastern Australia, A. japonicus juveniles are more abundant in brackish water (15 to $20 \%$, Gray \& McDonall 1993), while on the west coast where there are fewer estuaries mulloway occur in higher salinity environments (Loneragan et al. 1987). Mulloway abundance in rivers varies seasonally (Gray \& McDonall 1993), yet no other information on the habitat use or daily movements are available.

The present study employed acoustic telemetry to track movements of fish in an estuary to identify key habitat use and home range of Argyrosomus japonicus to optimise stocking efforts. The specific aims of the study were to compare juvenile and sub-adult mulloway in terms of (1) the key habitats necessary to support stocked mulloway in south-east Australian estuaries, (2) their home range and short-term movements, (3) their long-term fidelity to particular sites, and (4) their differences in day/night activity patterns.

\section{MATERIALS AND METHODS}

Study area. Botany Bay $\left(33.983^{\circ} \mathrm{S}, 151.200^{\circ} \mathrm{E}\right)$, New South Wales, Australia, is located in the southern Syd-

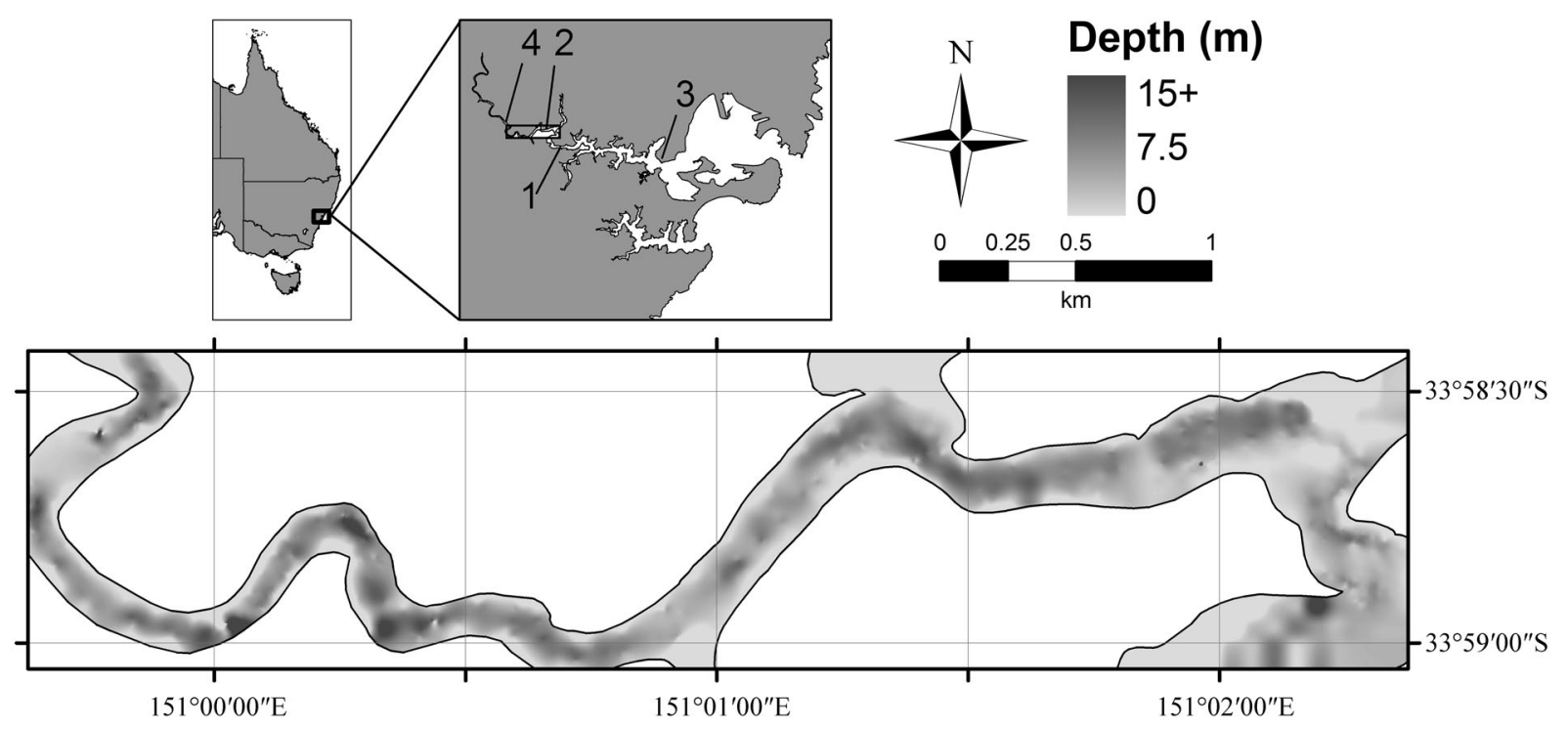

Fig. 1. Bathymetric map of the area used for $24 \mathrm{~h}$ tracking in Georges River, New South Wales, Australia. Solid lines indicate river shoreline and shading reveals the bathymetry and deep hole habitat. Inset map shows entire estuary and indicates release Sites (1) and (2), Captain Cook Bridge (3) and Sandy Point (4) 
Table 1. Argyrosomus japonicus. Fish implanted with ultrasonic tags in the Georges River, New South Wales, Australia

\begin{tabular}{|c|c|c|c|c|c|c|c|}
\hline Size class & Tag model ${ }^{\mathrm{a}}$ & Month & Release site & Algorithm $(\mathrm{h})^{\mathrm{b}}$ & Tag no. & $\mathrm{TL}(\mathrm{mm})$ & Fish no. $^{\mathrm{c}}$ \\
\hline \multirow{9}{*}{ Small } & \multirow{9}{*}{ IBT-96-2 } & \multirow{6}{*}{ Oct 2004} & \multirow{6}{*}{ Shallow } & $8 / 16$ & 1 & 340 & - \\
\hline & & & & $8 / 16$ & 2 & 340 & - \\
\hline & & & & $8 / 16$ & 3 & 380 & - \\
\hline & & & & $8 / 16$ & 4 & 350 & - \\
\hline & & & & $8 / 16$ & 5 & 330 & - \\
\hline & & & & $8 / 16$ & 6 & 390 & - \\
\hline & & \multirow[t]{3}{*}{ Jan 2005} & \multirow[t]{3}{*}{ Deep } & $24 / 0$ & 7 & 380 & $\mathrm{~F} 1, \mathrm{~F} 6$ \\
\hline & & & & $24 / 0$ & 8 & 400 & $\mathrm{~F} 2, \mathrm{~F} 7$ \\
\hline & & & & $24 / 0$ & 9 & 405 & F8 \\
\hline \multirow[t]{12}{*}{ Large } & \multirow[t]{7}{*}{ IT-95-2 } & May 2004 & Capture site & $24 / 0$ & 10 & 550 & - \\
\hline & & \multirow[t]{6}{*}{ Dec 2004} & \multirow[t]{6}{*}{ Capture site } & $24 / 0$ & 11 & 540 & - \\
\hline & & & & $24 / 0$ & 12 & 560 & - \\
\hline & & & & $24 / 0$ & 13 & 540 & - \\
\hline & & & & $24 / 0$ & 14 & 540 & - \\
\hline & & & & $24 / 0$ & $15^{\mathrm{d}}$ & 530 & F9 \\
\hline & & & & $24 / 0$ & $16^{\mathrm{d}}$ & 520 & F10 \\
\hline & \multirow[t]{5}{*}{ CT-82-2 } & \multirow[t]{5}{*}{ Dec 2004} & \multirow[t]{5}{*}{ Capture site } & $24 / 0$ & $17^{\mathrm{d}}$ & 730 & F3 \\
\hline & & & & $24 / 0$ & 18 & 640 & F11 \\
\hline & & & & $24 / 0$ & 19 & 660 & - \\
\hline & & & & $24 / 0$ & $20^{\mathrm{d}}$ & 555 & $\mathrm{~F} 4$ \\
\hline & & & & $24 / 0$ & $21^{\mathrm{d}}$ & 550 & F5, F12 \\
\hline \multicolumn{8}{|c|}{${ }^{a}$ Manufactured by Sonotronics } \\
\hline \multirow{2}{*}{\multicolumn{8}{|c|}{$\begin{array}{l}{ }^{\mathrm{b}} \text { Amount of time each day that the tag was turned on or off, e.g. } 8 / 16 \text { means the tag was on for } 8 \mathrm{~h} \text { and off for } 16 \mathrm{~h} \\
{ }^{\mathrm{c}} \text { Only fish included in the } 24 \mathrm{~h} \text { tracking were assigned fish numbers. Fish assigned } 2 \text { numbers were tracked over both track } \\
\text { ing period } 1 \text { (first number) and } 2 \text { (second number). Fish F1 to F5 were tracked in tracking period 1, while fish F6 to F12 wer } \\
\text { tracked in tracking period } 2\end{array}$}} \\
\hline & & & & & & & \\
\hline \multicolumn{8}{|c|}{${ }^{\mathrm{d} F i s h}$ that were tracked from January to November 2005} \\
\hline
\end{tabular}

ney metropolitan area with approximately $80 \mathrm{~km}^{2}$ of waterway area (Fig. 1). The Georges River $\left(33.998^{\circ} \mathrm{S}\right.$, $151.155^{\circ} \mathrm{E}$ ) extends $50 \mathrm{~km}$ upstream where the upper tidal limit is bounded by a weir (Fig. 1). The $800 \mathrm{~km}^{2}$ catchment of the Georges River discharges $\sim 3.2 \times$ $10^{8} \mathrm{~m}^{3}$ of water annually into Botany Bay (Bell \& Edwards 1980). The catchment has a waterway area of $12 \mathrm{~km}^{2}$, with $2 \mathrm{~km}^{2}$ of mangroves and $<1 \mathrm{~km}^{2}$ of seagrass and saltmarsh (Watford \& Williams 1998). The estuary is an important recreational waterway for Sydney residents with $\sim 700$ boat moorings, and over 40 local angler clubs. Both the river and the bay are subject to industrial pollution and have been significantly altered from their natural state through land reclamation for residential and industrial purposes (Gibbs 2001). The section of the estuary used in the present study (Fig. 1) corresponded to the optimal salinity range for mulloway (15 to $35 \%$ ).

Tracking equipment. Twenty-one cylindrical ultrasonic transmitters (Sonotronics), designed to transmit between 71 and $83 \mathrm{kHz}$, had a unique pulse rate/ frequency combination to allow identification of individual fish (Table 1). Transmitters were turned on for $24 \mathrm{~h} \mathrm{~d}^{-1}$, except some small IBT model transmitters that were programmed to run for $8 \mathrm{~h} \mathrm{~d}^{-1}$ to increase battery life (Table 1). Sonotronics manual tracking kits included a USR-96 acoustic receiver, a DH-4 directional hydrophone and Koss PRO-4AA headphones. The hydrophone was mounted facing forward on the side of the boat, and signals detected by the receiver were interpreted auditorily through the headphones. The receiver scanned relevant frequencies while the boat manoeuvred down the centre of the river at 4 to 8 knots, depending on tides or noise. When a signal was detected it was followed until an abrupt decrease in signal strength indicated that the boat passed over the transmitter. The boat was immediately turned around and a GPS waypoint marked where the signal was strongest. Bottom temperature, depth and salinity were also measured.

The range of the ultrasonic tags at $9 \mathrm{~m}$ depth was determined before implantation and release. A tag was attached to a mooring and tracked as distance increased from the mooring until the signal disappeared ( $\mathrm{n}=5$ replicates per pinger type). The minimum audible range of tags in a salinity of 25 was determined to be $324 \pm 12 \mathrm{~m}$ (mean $\pm \mathrm{SE}$ ). This is more than $175 \mathrm{~m}$ lower than the range specified by the manufacturer $(>500 \mathrm{~m})$, probably due to boat traffic noise. Human error in determining the exact location of a submerged pinger was assessed using a similar method, with a pinger attached to a mooring deployed 
in $11 \mathrm{~m}$ of water such that no part of the mooring was visible from the surface. A weighted rope was run from the mooring to the shore and secured underwater to allow retrieval of the mooring. The pinger was located 3 times during slack water, 3 times during an incoming tide and 3 times during an outgoing tide. Distances between the actual and measured location of the pinger were calculated using Mapsource v. 2 software (Garmin). Tracking error was calculated as $4.8 \pm 0.7 \mathrm{~m}$ $($ mean \pm SE), and GPS accuracy at $4.7 \pm 0.1 \mathrm{~m}$ (mean \pm $\mathrm{SE}$ ). Dead fish were identified by lack of any movement in the signal for more than $14 \mathrm{~d}$ and were excluded from the analyses (one wild fish and one hatchery-reared fish, not included in Table 1).

Surgical implantation of tags and release of fish. Juvenile Argyrosomus japonicus were grown at a commercial hatchery to $368.3 \pm 9.5 \mathrm{~mm}$ total length (TL mean $\pm \mathrm{SE}$ ), using extensive rearing techniques (Fielder \& Bardsley 1999). Mulloway were transported from the hatchery to aquaria in two 1201 tanks filled with seawater (salinity of 32, pH 7.5) and supplied with pure oxygen (1 to $21 \mathrm{~min}^{-1}$ ), and acclimatized to seawater in the aquarium (salinity of $35, \mathrm{pH}$ 8). Fish were immersed in an anaesthetic of $60 \mathrm{mg} \mathrm{l}^{-1}$ benzocaine in seawater and placed in a specially shaped operating cradle. A small horizontal incision into the gut cavity was made approximately $1 \mathrm{~cm}$ above the ventral midline, and a tag inserted. The wound was closed with both Epicon Vicaryl silk sutures (Johnson and Johnson) and Nexaband S/C cyanoacrylate surgical glue (Closure Medical), and $100 \mathrm{mg} \mathrm{ml}^{-1}$ engamycin antibiotic was injected intraperitonealy via the wound at a dose of $75 \mathrm{mg} \mathrm{kg}^{-1}$ body weight. An external T-bar tag (Hallprint) was inserted into the muscle surrounding the dorsal fin-spine using a tag gun. Information on the tag identified the presence of the transmitter, offered a reward and provided a phone number for the tag's return. Fish were held in a tank containing fresh seawater (salinity of 34, pH 8.0) until they regained consciousness. Surgery generally took 2 to $3 \mathrm{~min}$, and recovery to full consciousness and return to normal behaviour took approximately $5 \mathrm{~min}$. Fish were offered feed after $6 \mathrm{~h}$, and fed to satiation with $6 \mathrm{~mm}$ fishmealbased pellets (Skretting) twice a day. Fish were monitored for $5 \mathrm{~d}$ after surgery, after which the wound had healed. After $7 \mathrm{~d}$, fish were transported to release sites 1 and 2 (Fig. 1) as described above. Fish were acclimatized to conditions at the release sites (Site 1: salinity of 24, pH 8.2; Site 2: salinity of 26, pH 7.9) by exchanging water of decreasing salinity over a $60 \mathrm{~min}$ period and released into the estuary in $4 \mathrm{~m}$ (Site 1) or $12 \mathrm{~m}$ (Site 2) of water (Fig. 1).

Field-based surgery followed a similar procedure. Mulloway between 520 and $730 \mathrm{~mm}$ TL (583.2 \pm $18.6 \mathrm{~mm}$; mean $\pm \mathrm{SE}$ ) were captured by boat-based anglers using hook and line. Fish were lifted out of the water into on-board $200 \mathrm{l}$ flow-through tanks using a vinyl net to minimise scale damage, and hooks were removed. Fish were left for $30 \mathrm{~min}$ to recover from the stress of being landed before surgery commenced. After surgery, fish were placed back into the on-board tank and observed for 30 min after they regained consciousness. Fish were then held in the river and released within $15 \mathrm{~s}$. The minimum size of wild mulloway was larger than hatchery-reared fish; mulloway $<500 \mathrm{~mm}$ are not readily caught by hook and line because smaller mulloway target smaller prey than the bait used by mulloway anglers (M. Taylor unpubl. data).

Acoustic tracking. Hatchery-reared fish were released in groups (Table 1) and tracking commenced the day of release and continued daily over a complete lunar cycle. Each individual was located between 1 and 3 times $\mathrm{d}^{-1}$, depending on the total area covered to locate all fish. Tracking was undertaken within set boundaries (Fig. 1), from just east of the Captain Cook Bridge $\left(34.008^{\circ} \mathrm{S}, 151.130^{\circ} \mathrm{E}\right)$ to Sandy Point $\left(33.979^{\circ} \mathrm{S}\right.$, $\left.150.994^{\circ} \mathrm{E}\right)$, approximately $25 \mathrm{~km}$ upriver. Fish occasionally departed and returned to the tracking area; however, only movements inside the tracking area were considered in this study. Long-term tracking was carried out until 22 November 2005, with fish positions detected up to twice a month.

Up to 7 fish were tracked over $24 \mathrm{~h}$ periods to resolve day/night movement patterns (designated as Fish F1 to F12; Table 1). Tracking was undertaken as described above, within the boundary of Salt Pan Creek and Sandy Point (Fig. 1) where the majority of fish were concentrated. Fish had their positions fixed 3 to 4 times every $3 \mathrm{~h}$ for $3 \mathrm{~d}$ over the January new moon (tracking period 1: 9 to 11 January 2005) and full moon (tracking period 2: 24 to 26 January 2005). Fish remained within the tracking boundaries for the duration of both tracking events.

Analysis. High-resolution mapping was carried out in parts of Georges River to identify bathymetry and microhabitat characteristics (Fig. 1), with depth readings taken every 1 to $5 \mathrm{~m}$ to identify benthic structures such as boulders and vertical drops. A GPS waypoint and accuracy measurement were recorded for every depth reading, and depth readings were corrected for tide and standardised to Indian Spring Low Water (ISLW). A spatially continuous depth surface was generated from the GPS waypoints using a spline interpolator by means of the software ArcGIS v. 9 (ESRI 2005). Splines generated a smooth surface that approximated benthic variations.

Distances between waypoints and net movements were calculated using the software ArcGIS v. 9. All values accounted for the curvature of the river, and for long migrations distance was calculated along the centre of the river using ArcView 3.3. All depth measure- 
ments taken during tracking were corrected for tide and standardised to ISLW. Home range was calculated by means of ArcGIS v. 9 using quadratic kernel density estimates with a search radius of $150 \mathrm{~m}$ (Silverman 1986). The densities were weighted by the time fish spent in each position to better assess the home range usage by time. Home range was defined as the area within a contour incorporating $95 \%$ of the weighted kernel density. Core area within the $95 \%$ threshold was defined as area within the $50 \%$ contour of the weighted kernel density. The relationship between home range area and fish TL was evaluated using a linear regression analysis on $\log _{10}$ transformed 95 and $50 \%$ home range values. Home range values were also expressed as straight-line distances along the river incorporating $95 \%$ of points, for evaluation of long-term site fidelity.

A movement activity index (MAI, $\mathrm{m} \mathrm{h}^{-1}$ ) was calculated for $24 \mathrm{~h}$ of tracking by dividing the distance moved between waypoints by the time elapsed during this movement. Since movement between successive waypoints is unknown and straight line movement along the course of the river is assumed, MAI represents a minimum value. Non-metric multidimensional scaling (MDS) was performed to identify groupings of fish based on movement. An MDS plot was generated from a Euclidian similarity matrix of $\log _{10}$ transformed MAI measurements grouped for photoperiod (day, 10:00 to

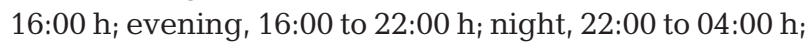
and morning, 04:00 to 10:00 h) and tide (flood, ebb and slack water, defined as $\Delta$ tide height $\left.0.1 \mathrm{~m} \mathrm{~h}^{-1}\right)$. Similarity percentages species contribution (SIMPER) analysis was run on the Euclidian similarity matrix for fish grouped by size (2-levels; small and large), to evaluate the contribution of the above species to MDS groupings.

Differences in movement patterns of fish released in different habitats were evaluated using a 2-sample $t$-test comparing net daily displacement $(\mathrm{m})$ of fish released in deep and shallow water for 1 to $3 \mathrm{~d}$ postrelease. We conducted an ANOVA to assess how variation in $\log _{10}$ transformed MAI measurements were partitioned between fish length, time and tide, with 3 fixed orthogonal factors including size (2 levels: small and large), photoperiod (4 levels: day, evening, night and morning) and tide ( 3 levels: flood, ebb and slack water). All statistical analyses were carried out using Systat v. 10 (SPSS), and multivariate statistics were performed using PRIMER v. 5.2.2 (PRIMER-E).

\section{RESULTS}

\section{General observations}

MDS on $\log _{10}$ transformed MAI measurements identified 2 distinct groups: fish $<500 \mathrm{~mm}$ TL (F1, F6, F7 and F8) grouped separately from fish $>500 \mathrm{~mm}$ TL (F3, F4, F5, F9, F10 and F11) with the exceptions of Fish F2 and F12 (Fig. 2). These groupings also corresponded with the origin of the fish as hatchery-reared or wild. The grouping of Fish F12 with small fish was the result of relative inactivity of the fish during the tracking period, and factors contributing to this are unknown. A stress value of 0.04 indicates the MDS plot accurately represents similarities. SIMPER analysis showed that MAI during the dawn on the ebb tide $(20 \%)$ and during the night on the flood tide $(15 \%)$ contributed most to these groupings. Fish F2 had an intermediate grouping, as night and dawn MAI values were larger than those in the $<500 \mathrm{~mm}$ grouping, but day and dusk MAI was smaller than those in the $>500 \mathrm{~mm}$ grouping. Fish were not analysed according to tracking undertaken during different moon phases (see Table 1) after inspection of the data. To maintain independence in subsequent home range and activity pattern analyses, individuals that were tracked during both the January new moon (tracking period 1) and full moon (tracking period 2; Table 1) phases had one tracking event randomly excluded from the data set for analyses.

\section{Key habitats}

Holes or basins were characterised as discrete depressions with respect to the surrounding area (Fig. 1), with relatively steep or near vertical edges. Small fish tended to reside in the immediate vicinity of sheer vertical faces within the holes or in holes of undulating topography. Time spent in and out of holes during the day and night showed small and large fish using holes similarly during the daytime,

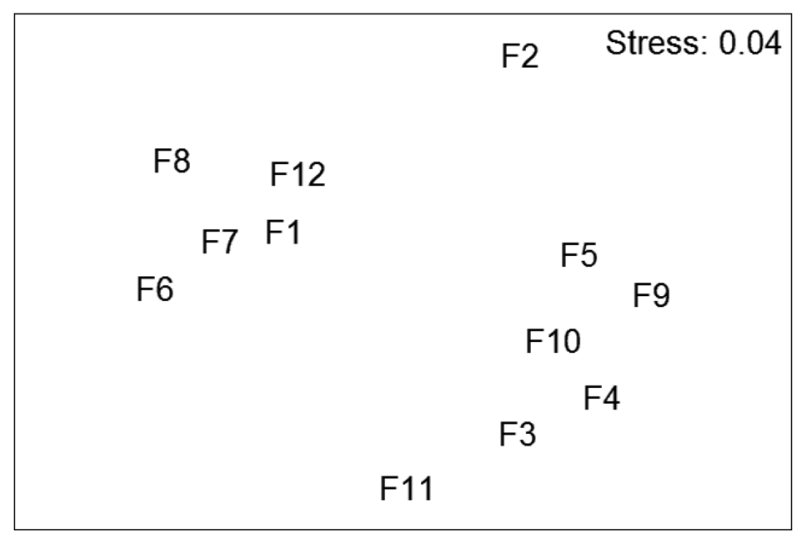

Fig. 2. Argyrosomus japonicus. Non-metric multidimensional (MDS) ordination of $\log _{10}$ transformed movement activity index (MAI) measurements using photoperiod (day, evening, night and morning) and tidal (flood, ebb and slack) data for Fish F1 to F12 
with fish spending the majority of daylight hours residing in hole habitat (Fig. 3). At night, large fish spent a greater percentage of time in shallower water, while small fish again spent the majority of time in the holes (Fig. 3).

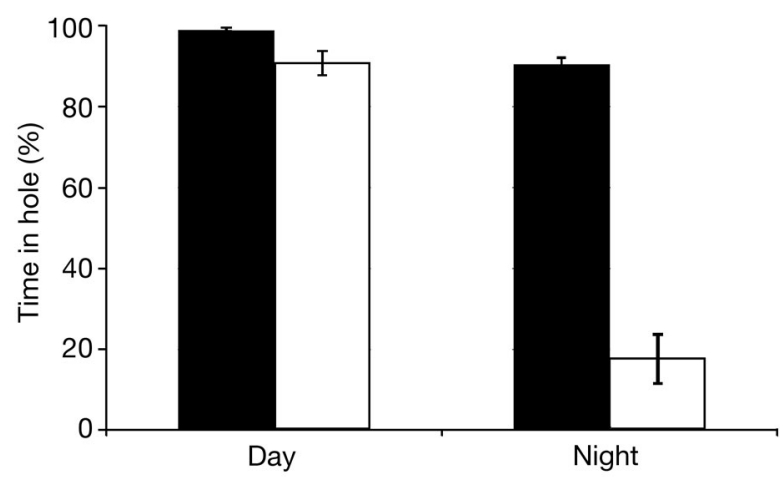

Fig. 3. Argyrosomus japonicus. Mean percent time \pm SE spent within key habitat during day and night for small (black bars) and large (white bars) fish

Table 2. Argyrosomus japonicus. Home range of fish in the Georges River. $50 \%$ areas represent summed core home range areas. TL: total length $(\mathrm{mm})$

\begin{tabular}{|lrrrcc|}
\hline Fish & TL & $\begin{array}{r}50 \% \\
\left(\mathrm{~m}^{2}\right)\end{array}$ & $\begin{array}{r}95 \% \\
\left(\mathrm{~m}^{2}\right)\end{array}$ & $\begin{array}{c}50: 95 \text { ratio } \\
(\%)\end{array}$ & $\begin{array}{c}\text { No.of } \\
\text { core areas }\end{array}$ \\
\hline F1 & 380 & 3260 & 5800 & 56 & 1 \\
F2 & 400 & 2980 & 5660 & 52 & 1 \\
F3 & 730 & 5750 & 10950 & 52 & 2 \\
F4 & 555 & 5450 & 8150 & 66 & 2 \\
F5 & 550 & 9200 & 17710 & 51 & 3 \\
F6 & 380 & 2440 & 4640 & 52 & 1 \\
F7 & 400 & 3180 & 6000 & 53 & 1 \\
F8 & 405 & 2550 & 4840 & 52 & 1 \\
F9 & 530 & 7180 & 13650 & 52 & 2 \\
F10 & 520 & 5130 & 9580 & 53 & 2 \\
F11 & 640 & 4500 & 8500 & 52 & 1 \\
F12 & 550 & 3860 & 7100 & 54 & 1 \\
\hline
\end{tabular}

\section{Home range and site fidelity}

Kernel analysis of home range identified up to 3 core (50\% contour) areas (mean of 2 ) used by individual fish (Table 2, Fig. 4a). Summed core home range areas were generally similar for fish within the 2 groups, as area standard error was $\sim 10 \%$ of the mean. Home range area showed a significant positive correlation with size for $50 \%$ contour $(r=0.69, p=0.04)$ and $95 \%$ contour estimates ( $r=0.71, p=0.03)$ (Fig. 5). The ratio of 50 to $95 \%$ contour areas (50:95) is a useful indicator of the level of residency in the core area of a home range (Parsons et al. 2003). Average 50:95 contour area ratios were close to $50 \%$ (Table 2 ), which showed that fish were generally using space within their home range evenly.

Large fish returned to the same hole that they left after their nightly migration in $92.9 \pm 4.6 \%$ (mean $\pm \mathrm{SE}$ ) of cases, sometimes passing over as many as 6 patches of key habitat to locate their original holes. Long-term tracking of 5 fish (F3, F4, F5, F9 and F10; Table 1) revealed strong site fidelity over the $11 \mathrm{mo}$ (Fig. 6). The number of fish detected within their home range was lower during the winter months, which coincided with a drop in river water temperature (Fig. 6), as they had potentially moved to the warmer waters of Botany Bay. All fish had returned to their home range by November 2005, 11 mo after tracking began, demonstrating a strong degree of site fidelity by wild mulloway in the Georges River.

\section{Activity patterns}

Small, hatchery-reared fish released into shallow water showed significantly higher net daily movement than small fish released directly into holes over the first $(t=-3.185, \mathrm{df}=8, \mathrm{p}=0.024)$ and second $(t=-6.231$, $\mathrm{df}=8, \mathrm{p}=0.001$ ) days post release (Fig. 7). An appar-

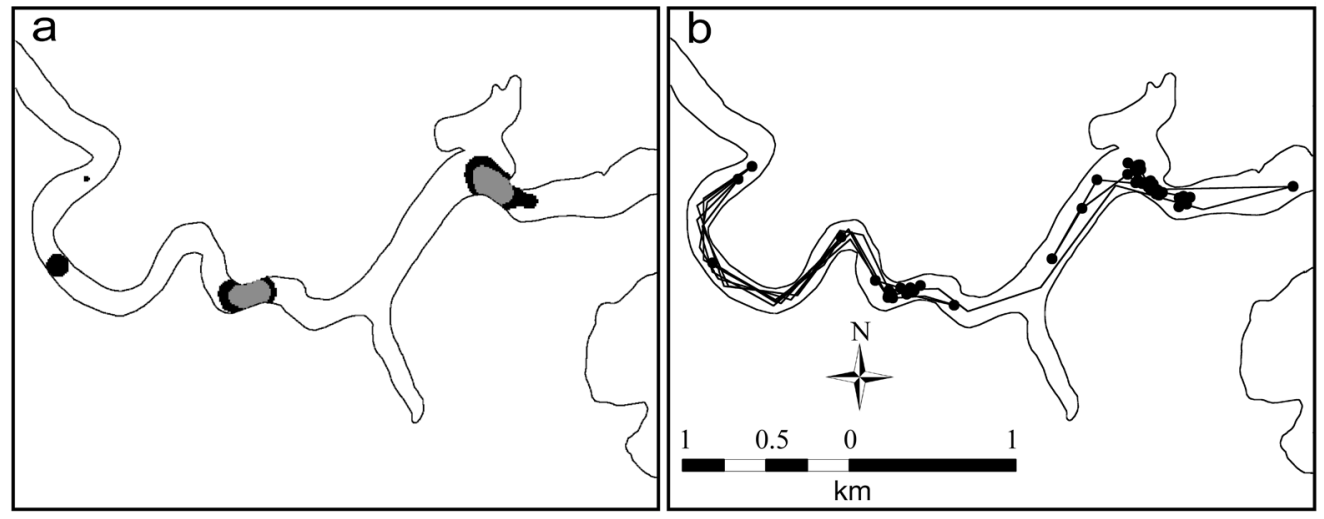

Fig. 4. Argyrosomus japonicus. Kernel distribution of (a) home range and (b) movement track over $72 \mathrm{~h}$ for Fish F9 (530 mm TL), showing 2 discrete core areas (grey shading) within the $95 \%$ contour area (black shading) in (a) 


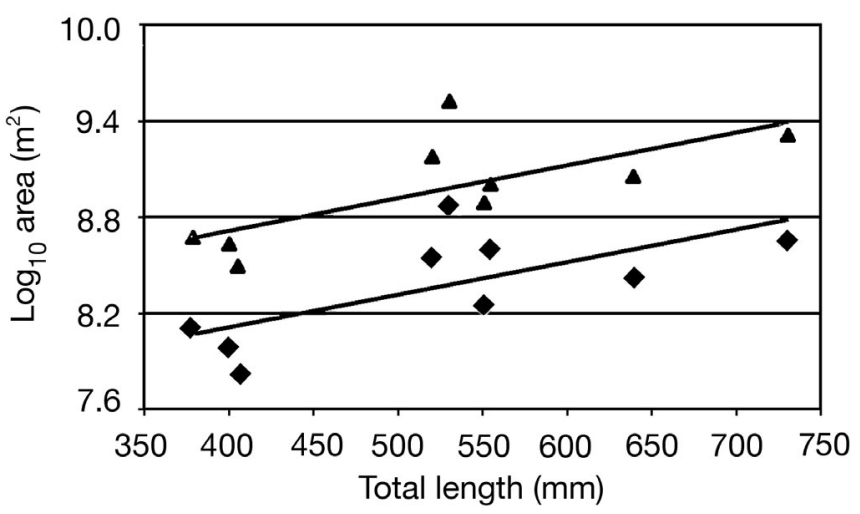

Fig. 5. Argyrosomus japonicus. Home range values from $24 \mathrm{~h}$ tracking by fish size, showing a significant correlation of $\log _{10}$ $50 \%(\diamond)$ and $95 \%(\Delta)$ contour values with size

ent higher movement from 3 to $6 \mathrm{~d}$ post release (Fig. 7) was not significant. Movement of small fish released in shallow water decreased $3 \mathrm{~d}$ after release, when the fish located a deep hole habitat (Fig. 7), although this was as far as $10 \mathrm{~km}$ from the release site. In some cases, fish passed over several deep holes before choosing a particular location. Small fish released directly into holes remained there and showed no difference in migratory behaviour during $20 \mathrm{~d}$ following release (Fig. 7).

Twelve wild caught fish tracked in January 2005 showed variable movement among fish and among days (Fig. 7), with fish migrating up to $16 \mathrm{~km}$ between consecutive daily tracking events. Fish migrated up to $53 \mathrm{~km}$ over the $20 \mathrm{~d}$ period, and some were found to leave the river to enter Botany Bay for a number of days before returning (on such occasions their absence from the river was noted, but movement was not detected).

The majority of variance in $\log _{10}$ MAI was due to the size of the fish (Table 3), with large wild fish having a significantly higher MAI (Fig. 8). Most of the remaining variance was attributed to photoperiod, with significantly less movement during the day compared with that at night (Tukey's, $\mathrm{p}<0.001$ ) and day compared with morning (Tukey's, p < 0.001) (Fig. 8). Large wild fish typically had an area within a hole in which movement was concentrated during the day, and 1 or 2 areas outside this where the fish went to forage (e.g. Fig. 4b). Small hatchery-reared fish movement was concentrated within one discrete area (Table 2) within a hole (Fig. 3). Whilst tide had no significant effect on MAI ( $p=0.054$; Table 3$)$, a Type II error is possible in the comparison given this significance level.

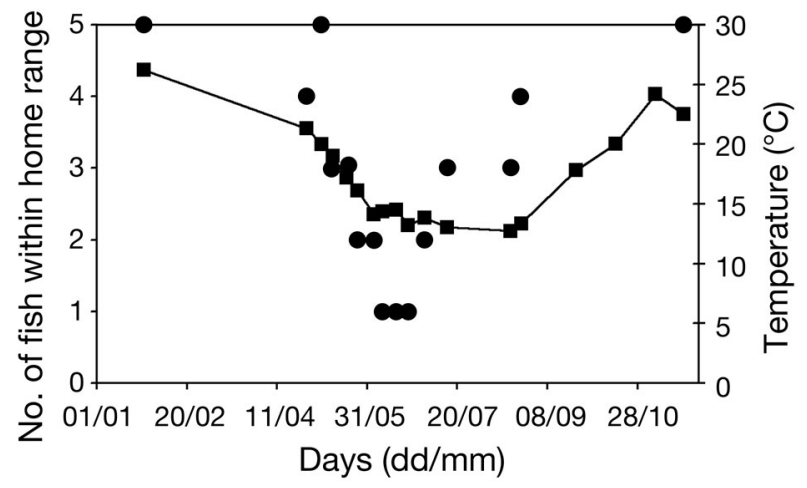

Fig. 6. Argyrosomus japonicus. Number of fish detected within straight-line home ranges for $11 \mathrm{mo}$ in 2005 (๑), and corresponding changes in river temperature (

\section{DISCUSSION}

\section{Activity patterns}

The direct observations of movement patterns in this study have given a new insight into mulloway habitat use and activity patterns, revealing crepuscular activity and diel variation in movement of Argyrosomus japonicus and specialised habitat use. Key habitats for mulloway are areas of discrete deep water, especially with bottom structure or submersed cliffs. Mulloway are relatively sedentary fish that rarely undertake episodes of sustained swimming within the estuary (although mature fish do make coastal migrations, West 1992). Fish tracked during the $24 \mathrm{~h}$ tracking events resided within the $15 \mathrm{~km}$ stretch of river for at least $72 \mathrm{~h}$, and total nightly movements rarely ex-

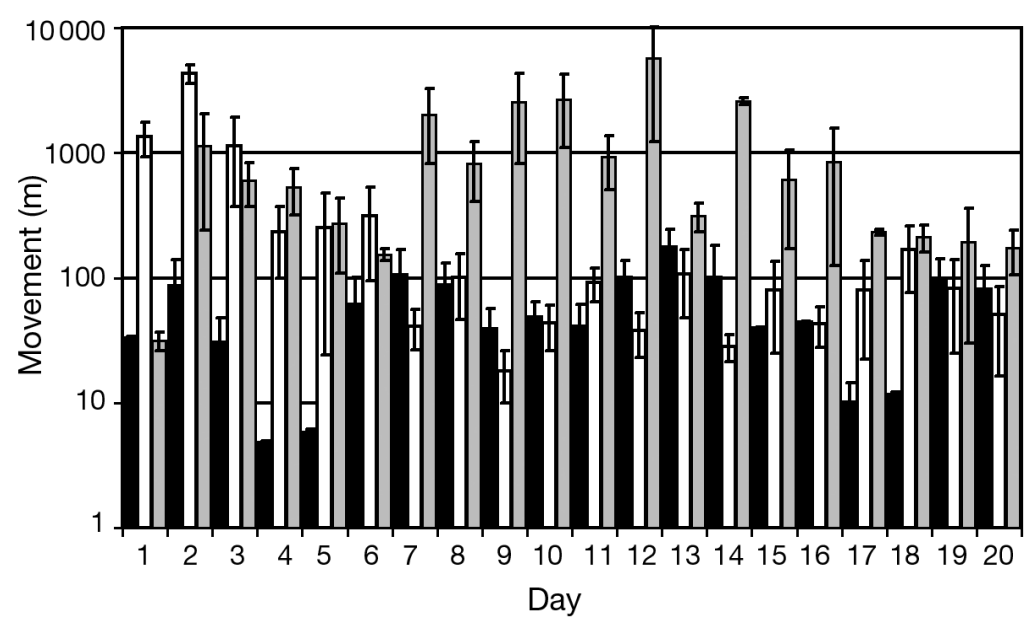

Fig. 7. Argyrosomus japonicus. Mean daily migration \pm SE of hatcheryreared mulloway released in deep (black bars; $\mathrm{n}=3$ ) and shallow (white bars; $\mathrm{n}=6$ ) water habitats, and wild mulloway (grey bars; $\mathrm{n}=12$ ) tracked in the Georges River. Tracking was carried out over spring and summer 2004-05 for periods of $20 \mathrm{~d}$ 
Table 3. Argyrosomus japonicus. ANOVA for movement activity index (MAI) measurements among different sizes (small and large), photoperiods (day, evening, night and morning) and tides (flood and ebb). df: degrees of freedom; MS: mean square. ${ }^{*} \mathrm{p}<0.05,{ }^{* *} \mathrm{p}<0.01$

\begin{tabular}{|lcccc|}
\hline Source of variation & df & $\begin{array}{c}\text { MAI } \\
\text { MS }\end{array}$ & $F$ & $p$ \\
\hline Size & 1 & 5.58 & 45.37 & $<0.001^{* *}$ \\
Photoperiod & 3 & 0.4 & 3.96 & $0.012^{*}$ \\
Tide & 2 & 0.48 & 3.88 & 0.054 \\
Size $\times$ Photoperiod & 3 & 0.15 & 1.18 & 0.33 \\
Size $\times$ Tide & 2 & 0.05 & 0.44 & 0.50 \\
Photoperiod $\times$ Tide & 6 & 0.12 & 0.94 & 0.48 \\
Size $\times$ Photoperiod $\times$ Tide & 6 & 0.06 & 0.51 & 0.78 \\
Error & 56 & 0.12 & & \\
\hline
\end{tabular}

ceeded $3 \mathrm{~km}$. Some individuals had particular movement patterns with some large animals moving up to $7.5 \mathrm{~km} \mathrm{~d}^{-1}$ compared with other large animals moving only $1 \mathrm{~km} \mathrm{~d}^{-1}$. Mulloway are morphologically specialised for acceleration but not for sustained cruising, as shown by the aspect ratio of the caudal fin (Pauly 1989). Similarly, Australian Plectropomus leopardus have an aspect ratio (Froese \& Pauly 2003, available at www.fishbase.org) comparable with mulloway and only undertake smaller total daily migrations $(0$ to $1121 \mathrm{~m})$; however, activity is typically greater during the day (Zeller 1997). MAI indicates that large fish are significantly more active than smaller fish, with significantly greater movement in night and morning.

The size comparisons made in this study, while interesting, are potentially confounded as fish included in the smaller group were sourced from a hatchery rather than from wild stock. Hatchery-reared fish are potentially naïve to both prey and predators in the natural environment, and may consequently display different behaviour to that of wild fish (Berejikian 1995, Kellison et al. 2000). While the effects of origin and size cannot be separated with the current dataset, the ecological interpretation and implications of differing habitat use for stocking are valid. The relative movements of small wild and large hatchery-reared fish remain important questions for future research.

Mulloway were separated into 2 distinct groups based on MAI, which may correspond to different forage- and risk-related behaviour. Night and morning activity was characterised by movement outside of hole habitat for large wild mulloway, and within hole habitat for small hatchery reared mulloway. Day activity was characterised by lower MAI than for night, with both large and small mulloway remaining in holes. Nocturnal and crepuscular predation is common among other members of Sciaenidae including Plagioscion squamosissimus (Hahn et al. 1999), African Argyrosomus japonicus (Hecht \& Mperdempes 2001) and Larimus breviceps (Soares \& Vazzoler 2001). This photoperiod dependent activity may relate to both increased foraging efficiency and minimisation of predation risk for smaller fish, as such transitions often represent a shift in activity between feeding and sheltering (e.g. Hodgson 1972). Periods of greatest mulloway movement coincide with the most active period of small herrings (Talbot \& Baird 1985, Emmett et al. 2004, Krutzikowsky \& Emmett 2005), a major prey item for mulloway (M. Taylor unpubl. data). However, differences in habitat use by small and large mulloway may be a function of smaller fish minimising predation risk by avoiding the foraging (non-hole) habitats exploited by large, cannibalistic conspecifics that are less vulnerable to predation. Shifts in habitat use often correspond to transitions where predation risk becomes lower, as habitat choice involves a trade-off between predation risk and forage requirements (Mittelbach 2002). Such transitions were observed in killifish Fundulus heteroclitus, where juveniles sought refuge in intertidal habitats when larger cannibalistic conspecifics were absent at low tide (Kneib 1987). The tendency of smaller juvenile mulloway to inhabit 'edge' habitats (e.g. up against a rock wall or in a crevice), suggest that these habitats afford some refuge from tidal currents and predation. While small mulloway spend the majority of time in these edge habitats, large mulloway are not confined to more protective edge areas.

This study represents the first estimates of home range size for Argyrosomus japonicus. Kernel home range estimates for mulloway varied between 2440 and $9200 \mathrm{~m}^{2}$ for the $50 \%$ contour, and 4640 and $17710 \mathrm{~m}^{2}$ for the $95 \%$ contour, and were significantly correlated with size. These home range values are to be expected considering the width of the Georges River; however, in less spatially constrained habitats

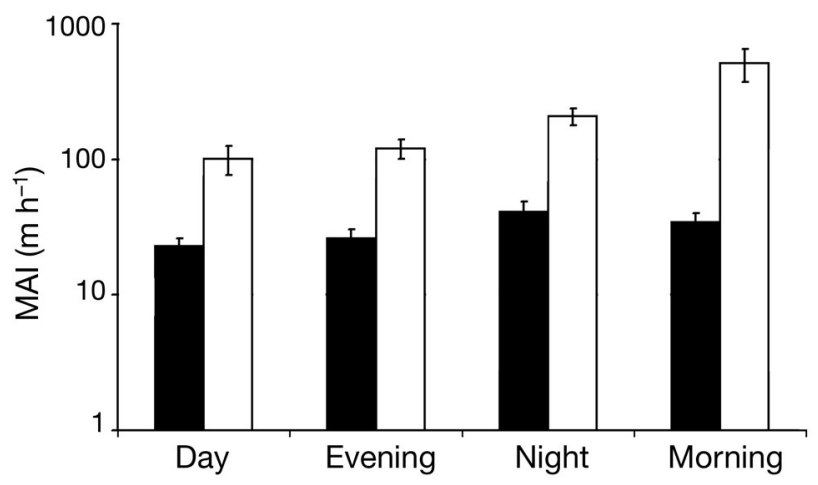

Fig. 8. Argyrosomus japonicus. Mean \pm SE MAI measurements for $24 \mathrm{~h}$ tracking of small (black bars) and large (white bars) fish by photoperiod (day, 10:00 to $16: 00 \mathrm{~h}$; evening, 16:00 to $22: 00 \mathrm{~h}$; night, 22:00 to $04: 00 \mathrm{~h}_{\text {; }}$ and morning, 04:00 to $10: 00 \mathrm{~h})$ 
such as nearshore reefs and estuarine embayments home range may be greater. Home range $(95 \%)$ of the reef dwelling fish Pagrus auratus were as large as $50000 \mathrm{~m}^{2}$, yet they spent $50 \%$ of their time in an area only 3.6 to $16.3 \%$ of the total home range area (Parsons et al. 2003). Use of the home range area was uniform for mulloway with $50 \%$ of time being spent in $~ 53 \%$ of the home range area, as occasional large movements of mulloway contributed little to estimates of home range as time spent on these was relatively short. Large fish had an average of 2 activity centres, possibly due to different foraging and resting locations.

Homing behaviour observed in mulloway is not unexpected, as it is a common strategy to stabilise spatial distribution (Parker 1995, Lowry \& Suthers 1998, Thorrold et al. 2001). Each hole appeared to have a characteristic salinity (data not presented), depending on hole depth and current movements, which may have provided a signature to facilitate homing. Spatial learning of home range bathymetry may allow fish to navigate back to resting or foraging sites, or both (Kaunda-Arara \& Rose 2004). The departure and return of fish to their home ranges has implications for carrying capacity of the ecosystem. Site fidelity may impose competition for a limited resource such as space and food (e.g. Sikkel 1998, Matthiopoulos et al. 2005); however, as juvenile mulloway are non-territorial, production, rather than space, may limit the carrying capacity of key habitats. Investigation of juvenile density-dependence within key habitats will reveal if this is the case.

Detection of movement at fine temporal scales provides new insight into the relationship between habitat use and movement patterns as observed in this study. Studies that use positional fixes at larger temporal intervals will mask any within-day variability in movement and habitat use. This is particularly relevant in assessments of movement for species that undertake large foraging excursions at times when fish may not be tracked (i.e. at night, Baras 1998). Tracking studies should include a continual tracking component, to identify potential masking of movement and home range estimates. Whilst continual tracking is labour intensive, the recent advent of low-cost acoustic listening stations allows continual tracking with relatively little time investment (Heupel et al. 2006). The approach adopted in this experiment involved the use of Geographic Information Systems (GIS) to process and analyse spatial habitat characteristics such as bathymetry; however, the application in studies of home range and habitat use has been limited (Eristhee \& Oxenford 2001, Topping et al. 2005, Righton \& Mills 2006). With the increasing use of acoustic tagging studies to evaluate effectiveness of marine reserves (Parsons et al. 2003, Popple \& Hunte 2005), such stud- ies of habitat use could clearly benefit from adopting such an approach (e.g. Topping et al. 2005).

\section{Implications for stock enhancement}

Acoustic tracking has provided valuable data on the key habitats required for juvenile mulloway, thus allowing various target release sites to be evaluated in terms of enhancement potential. Success of previous mulloway enhancement attempts has been variable and limited to estuaries that have a large area of key habitat (discrete deep holes with bottom structure, Taylor et al. 2006). The specific habitat requirements of mulloway have implications for stocking, as fish released in shallow water spent $3 \mathrm{~d}$ undertaking large movements that were uncharacteristic of fish stocked in deep water habitats. Fish are generally stressed after transport to the stocking site (Taylor et al. 2005) and may be partially starved due to the logistics and the maintenance of water quality during transport. Stocking large numbers of fish at a convenient location such as a boat ramp is a common approach to release hatchery fish (Rimmer \& Russell 1998, Fielder et al. 1999). Aside from the effects of high predation at the stocking site, the associated physiological stress and bioenergetic toll of stocking mulloway in shallow water may have significant detrimental effects on survival. The cost of transport by boat and stocking directly into key habitats could be more than offset by greater survival of stocked fish; however, this remains to be tested. In addition, as potential risk sensitive behaviour of small mulloway indicates they may be hiding from predators (Walters \& Kitchell 2001), an overstocked ecosystem could potentially saturate deep holes and associated refugia. Consequently, mortality may reduce fish numbers until the population reaches a sustainable level.

The effect of naïvety on migration (MAI) cannot be determined without comparison with the movement of small, wild fish. Mulloway, however, are cannibalistic and do experience predators (such as larger conspecifics) and prey (plankton, mysid shrimp and smaller conspecifics) in the hatchery environment. Assuming that hatchery-reared fish behave in the same way as wild fish of the same size, mulloway may adopt natural foraging behaviour relatively soon after release, as there was no significant difference between the partitioning of time for small, potentially naïve fish and wild fish. If small fish were naïve to conditions in the wild in tracking period 1 ( 2 to $5 \mathrm{~d}$ after release), they may well have learned additional behavioural traits by tracking period 2, 15 d later. Diel patterns in feeding may not necessarily be a learned behaviour and may even be instilled in the fish whilst in the hatchery. The full extent of naïvety of hatchery-reared 
mulloway remains unknown despite our attempts to address this. If mulloway were naïve, behaviour would have most probably been learned quickly through interaction with wild conspecifics (Olla et al. 1998), as naïve fish have generally learned necessary foraging behaviours within $14 \mathrm{~d}$ of release (Kristiansen \& Svåsand 1992). Our observations of site fidelity are particularly important for restocking of estuaries. Funds for restocking are derived from particular clubs, who obviously wish to benefit from their efforts, but anecdotal information suggest mulloway may leave when the estuary becomes cooler than the bay or coastal ocean. We believe these sub-adult fish simply move into Botany Bay to benefit from the warmer saltwater wedge, and not the coastal ocean. At maturity (80 cm TL), mulloway begin undertaking extended coastal migrations (West 1992).

Acoustic telemetry has provided new information regarding the complex associations between habitat use and activity for Argyrosomus japonicus; however, several areas remain to be examined. African A. japonicus have been shown to move between near and offshore habitats depending on season (Griffiths 1997), and anecdotal information suggests Australian A. japonicus behave similarly (West 1992). As key habitats and daily activity patterns have now been defined, future work should resolve the seasonal variability in the distribution of mulloway in south-eastern Australia.

Acknowledgements. This work was supported in part by a grant from the New South Wales Recreational Saltwater Fishing Trust (to I.M.S., D.S.F. and M.D.T.), and an Australian Research Council Linkage Grant (\#LP0219596) to I.M.S. and D.S.F., with University of New South Wales animal care and ethics approval (ACEC \#02/115). The authors thank A. O'Donohue, T. Mullaney, J. Everett, C. Hollows, M. Ives, H. El-Hassan, R. Forward, R. Cartwright, P. Burns, D. Booth, K. Taylor and M. Lowry for assistance in various areas of this study. Our 3 anonymous reviewers greatly improved the manuscript.

\section{LITERATURE CITED}

Baras E (1998) Selection of optimal positioning intervals in fish tracking: an experimental study on Barbus barbus. Hydrobiologia 371/372:19-28

Bell F, Edwards A (1980) An environmental inventory of estuaries and coastal embayments in New South Wales. Total Environment Centre, Sydney

Berejikian B (1995) The effects of hatchery and wild ancestry and experience on the relative ability of steelhead trout fry (Oncorhynchus mykiss) to avoid a benthic predator. Can J Fish Aquat Sci 52:2476-2482

Blankenship HL, Leber KM (1995) A responsible approach to marine stock enhancement. Am Fish Soc Symp 15: $167-175$

Bradford R, Gurtin S (2000) Habitat use by hatchery-reared adult razorback suckers released into the Lower Colorado River, California-Arizona. N Am J Fish Manag 20:
$154-167$

Cooney RT, Thomas GL, Mathisen OA (1993) A theoretical evaluation of the carrying capacity of Prince William Sound, Alaska, for juvenile Pacific salmon. Fish Res 18: 77-87

Emmett R, Brodeur RD, Orton P (2004) The vertical distribution of juvenile salmon (Oncorhynchus spp.) and associated fishes in the Columbia River plume. Fish Oceanogr 13:392-402

Eristhee N, Oxenford HA (2001) Home range size and use of space by Bermuda chub Kyphosus sectatrix (L.) in two marine reserves in the Soufriere Marine Management Area, St Lucia, West Indies. J Fish Biol 59:129-151

Fielder DS, Bardsley WJ (1999) A preliminary study on the effects of salinity on growth and survival of mulloway Argyrosomus japonicus larvae and juveniles. J World Aquacult Soc 30:380-387

Fielder DS, Bardsley WJ, Allan GL (1999) Enhancement of mulloway (Argyrosomus japonicus) in intermittently opening lagoons. NSW Fisheries Final Report Series No. 14, New South Wales Fisheries, Cronulla

Gibbs PJ (2001) Monitoring of natural recolonisation of seagrass and transplant success of Zostera capricorni at the Sydney Airport third runway in Botany Bay. Final Report to Sydney Airports Corporation Limited and Sydney Ports Corporation, Sydney Airports Corporation, Sydney

Gray CA, McDonall VC (1993) Distribution and growth of juvenile mulloway, Argyrosomus hololepidotus (Pisces, Sciaenidae), in the Hawkesbury River, South-Eastern Australia. Aust J Mar Freshw Res 44:401-409

Griffiths MH (1997) Influence of prey availability on the distribution of dusky kob Argyrosomus japonicus (Sciaenidae) in the Great Fish River Estuary, with notes on the diet of early juveniles from three other estuarine systems. S Afr J Mar Sci 18:137-145

Hahn N, Loureiro V, Delariva R (1999) Curvina Plagioscion squamosissimus (Heckel, 1840) (Perciformes, Sciaenidae) feeding activity in Parana River. Acta Sci 21:309-314

Hecht T, Mperdempes A (2001) Screening of Argyrosomus japonicus (Sciaenidae) and Pomadasys commersonnii (Haemulidae) as candidates for aquaculture in South Africa. Aquaculture 2001 Book of Abstracts. World Aquaculture Society, Coronado Springs Resort, FL

Henry GW, Lyle JM (2003) The national recreational and indigenous fishing survey. Australian Government Department of Agriculture, Fisheries and Forestry, Canberra

Heupel MR, Semmens JM, Hobday AJ (2006) Automated acoustic tracking of aquatic animals: scales, design and deployment of listening station arrays. Mar Freshw Res 57: $1-13$

Hodgson E (1972) Activity of Hawaiian reef fishes during the evening and morning transitions between daylight and darkness. Fish Bull 70:715-740

Holland K, Brill R, Ferguson S, Chang R, Yost R (1985) A small vessel technique for tracking pelagic fish. Mar Fish Rev 47:26-32

Kaunda-Arara B, Rose GA (2004) Homing and site fidelity in the greasy grouper Epinephelus tauvina (Serranidae) within a marine protected area in coastal Kenya. Mar Ecol Prog Ser 277:245-251

Kellison GT, Eggleston DB, Burke JS (2000) Comparative behaviour and survival of hatchery-reared versus wild summer flounder (Paralichthys dentatus). Can J Fish Aquat Sci 57:1870-1877

Kneib RT (1987) Predation risk and use of intertidal habitats by young fishes and shrimp. Ecology 68:379-386 
Kristiansen T, Svåsand T (1992) Comparative analysis of stomach contents of cultured and wild cod, Gadus morhua L. Aquac Fish Manag 23:661-668

Krutzikowsky G, Emmett R (2005) Diel differences in surface trawl fish catches off Oregon and Washington. Fish Res 71: 365-371

Loneragan NR, Potter IC, Lenanton RCJ, Caputi N (1987) Influence of environmental variables on the fish fauna of the deeper waters of a large Australian estuary. Mar Biol 94:631-641

Lowry MB, Suthers IM (1998) Home range, activity and distribution patterns of a temperate rocky-reef fish, Cheilodactylus fuscus. Mar Biol 132:569-578

Matthiopoulos J, Harwood J, Thomas L (2005) Metapopulation consequences of site fidelity for colonially breeding mammals and birds. J Anim Ecol 74:716-727

McEachron LW, Daniels K (1995) Red drum in Texas: a success story in partnership and commitment. Fisheries (Am Fish Soc) 20(3):6-8

Miller JM, Walters C (2004) Experimental ecological tests with stocked marine fish. In: Leber K, Kitada S, Blankenship HL, Svåsand T (eds) Stock enhancement and sea ranching: developments, pitfalls and opportunities. Blackwell, Oxford, p 142-152

Mittelbach G (2002) Fish foraging and habitat choice: a theoretical perspective. In: Hart PJB, Reynolds JD (eds) Handbook of fish biology and fisheries, Vol 1. Blackwell, Oxford, p 251-266

Olla BL, Davis MW, Ryer CH (1998) Understanding how the hatchery environment represses or promotes the development of behavioural survival skills. Bull Mar Sci 62: $531-550$

Parker S (1995) Homing ability and homerange of yellowphase American eels in a tidally dominated estuary. J Mar Biol Assoc UK 75:127-140

Parsons D, Babcock R, Hankin R, Willis T, Aitken J, O'Dor R, Jackson G (2003) Snapper Pagrus auratus (Sparidae) home range dynamics: acoustic tagging studies in a marine reserve. Mar Ecol Prog Ser 262:253-265

Pauly D (1989) Food consumption by tropical and temperate fish populations: some generalisations. J Fish Biol 35 (Suppl A):11-20

Popple ID, Hunte W (2005) Movement patterns of Cephalopholis cruentata in a marine reserve in St Lucia, WI, obtained from ultrasonic telemetry. J Fish Biol 67: 981-992

Righton D, Mills C (2006) Application of GIS to investigate the use of space in coral reef fish: a comparison of territorial behaviour in two Red Sea butterflyfishes. Int J Geogr Inf Sci 20:215-232

Rimmer MA, Russell DJ (1998) Survival of stocked barramundi, Lates calcarifer (Bloch), in a coastal river system

Editorial responsibility: Otto Kinne (Editor-in-Chief), Oldendorf/Luhe, Germany in far Northern Queensland, Australia. Bull Mar Sci 62:325-335

Salvanes AGV, Aksnes D, Giske J (1992) Ecosystem model for evaluating potential cod production in a west Norwegian fjord. Mar Ecol Prog Ser 90:9-22

Sikkel PC (1998) Competitor intrusions and mate-search tactics in a territorial marine fish. Behav Ecol 9:439-444

Silberschneider V, Gray C (2005) Arresting the decline of the commercial and recreational fisheries for mulloway (Argyrosomus japonicus). NSW DPI Fisheries Final Report Series No. 82, New South Wales Fisheries, Cronulla

Silverman BW (1986) Density estimation for statistics and data analysis. Chapman \& Hall, New York

Smale MJ (1985) Aspects of the biology of Argyrosomus hololepidotus and Atractoscion aequidens (Osteichthyes: Sciaenidae) in waters of the Southeastern Cape South Africa. S Afr J Mar Sci 3:63-76

Soares L, Vazzoler A (2001) Diel changes in food and feeding activity of sciaenid fishes from the south-western Atlantic, Brazil. Braz J Biol 61:197-216

Talbot M, Baird D (1985) Feeding of the estuarine round herring Gilchristella aestuarius (Stolephoridae). J Exp Mar Biol Ecol 87:199-214

Taylor MD (2006) Environmental impact of stocked mulloway (Argyrosomus japonicus) in New South Wales estuaries. PhD thesis, University of New South Wales, Sydney

Taylor MD, Palmer PJ, Fielder DS, Suthers IM (2005) Responsible estuarine finfish stock enhancement: an Australian perspective. J Fish Biol 67:299-331

Thorrold SR, Latkoczy C, Swart PK, Jones CM (2001) Natal homing in a marine fish metapopulation. Science 291: 297-299

Topping DT, Lowe CG, Caselle JE (2005) Home range and habitat utilization of adult California sheephead, Semicossyphus pulcher (Labridae), in a temperate no-take marine reserve. Mar Biol 147:301-311

Walters CJ, Kitchell J (2001) Cultivation/depensation effects on juvenile survival and recruitment: implications for the theory of fishing. Can J Fish Aquat Sci 58:39-50

Walters CJ, Martell S (2004) Fisheries ecology and management. Princeton University Press, Princeton, NJ

Watford F, Williams R (1998) Inventory of estuarine vegetation in Botany Bay with special reference to change in the distribution of seagrass. NSW Fisheries Final Report Series No. 11, New South Wales Fisheries, Cronulla

West RJ (1992) Mulloway. The Australian Anglers Fishing World, August 1992. Yaffa Publishing Group, Sydney, p 84-85

Zeller D (1997) Home range and activity patterns of the coral trout Plectropomus leopardus (Serranidae). Mar Ecol Prog Ser 154:65-77

Submitted: September 21, 2005; Accepted: June 14, 2006

Proofs received from author(s): December 4, 2006 